Ukrainian language and literature: monograph]. Sumy, 404 p. [in Ukrainian].

5. Symenenko, T. V. (2007). Formuvannia profesiinoi movnokomunikatyvnoi kompetentsii studentiv filolohichnykh fakultetiv [Formation of professional linguistic-communicative competence in students of philological faculties]. Extended abstract of Doctor's thesis. Kyiv, 28 p. [in Ukrainian].

6. Slyzhuk, O. A. (2011). Formuvannia maisternosti maibutnikh uchyteliv-slovesnykiv pid chas pedahohichnoi praktyky [Formation of mastership in future communication-teachers during pedagogical practice]. Methodology and theory of pedagogy. Scientific notes of the National State University named after Mykola Hohol, 5.pp.114-116. [in Ukrainian].

7. Toptyhina, N. Pedahohichna praktyka yak skladovyi komponent profesiinoi pidhotovky maibutnikh uchyteliv
[Pedagogical practice like composing component of professional future teacher's training]. Scientific articles and publications. [in Ukrainian].

8. Shumarova, I.P. (2000). Movna kompetentsiia osobystosti v sytuatsiiakh bilinhvizmu: monohrafiia [Linguistic competence of the individuality in bi-linguistic situations]. Kyiv, 283 p. [in Ukrainian].

9. El-Mowafy, A., Kuhn, M. \& Snow, T. Blended learning in higher education: Current and future challenges in surveying education. In Special issue: Teaching and learning in higher education: Western Australia's TL Forum. Issues In Educational Research, 23(2), pp.132-150. URL: http://www.iier.org.au/iier23/el-mowafy.html [in English].

10. Marshall, H. Three reasons to flip your classroom / / Bilingual Basics. August, 2013. URL: http:// newsmanager.commpartners.com/tesolbeis/issues/201308-28/6.html[in English].

Стаття надійшла до редакції 25.02.2019

УДК 378(043.5)

DOI:

Надія Смолікевич, кандидат педагогічних наук, асистент кафедри іноземних мов для природничих факультетів Львівського національного університету імені Івана Франка

\title{
ЗАБЕЗПЕЧЕННЯ ЯКОСТІ УНІВЕРСИТЕТСЬКОЇ ОСВІТИ США
}

У статті проаналізовано головні характеристики університетської освіти США з точки зору ії організаційного, змістового та теоретико-методологічного контекстів, передумови ї̈ забезпечення, світовий рейтинг найкращих університетів і передові позиції університетів США, розглянуто діяльність, мету та стратегічні иілі ЗВО США. Охарактеризовано роль держави в управлінні та фінансуванні вищоі освіти, освітню політику на міжнародному рівні, що підтримує інтернаціоналізаџฺю, високі стандарти та спрямована на збільшення кількості іноземних студенів.

Ключові слова: університетська освіта США; якісні освітні послуги; управління вищою освітою; інтернаціоналізація; діяльність $3 B O$.

Табл. 2. Літ. 12.

Nadiya Smolikevych, Ph.D.(Pedagogy), Assistant of the Foreign Languages for Natural Sciences Faculties Department Lviv Ivan Franko National University

\section{SUPPORTING THE QUALITY OF USA UNIVERSITY EDUCATION}

The main characteristics of the USA university education in terms of its organizational, content, and theoretical and methodological contexts, the prerequisites for its supporting, the world ranking of the best universities and the leading positions of the USA universities has been analyzed in the article. I also has been reviewed the activities, goals and strategic objectives of the USA universities. The role of the state in the management and financing of higher education, an international educational policy that supports internationalization, high standards and aims at increasing the number of foreign students has been characterized.

It has been stated that the important characteristics of high-quality higher education in the United States are: the relevance of higher education to the needs of the global economy, possibility of choosing contemporary specialties, high-quality, modern, practical education with a world-class diploma; competitive requirements for entering the university, the appropriate level of entrants; programs with a multicultural component; pre-university training and language training programs; teachers and scientists with practical experience (domestic and from abroad), application of IT technologies in educational process; promotion and realization of scientific researches, classes with a small number of students; individual approach to each student; the opportunity to study in an individual program, to win grants for training; the practice of choosing a specialty after two years of study; appropriate activity of counseling centers in teaching, social and cultural adaptation; modern material and technical base; learning experience in a diverse environment; the opportunity to make useful acquaintances and find friends, 
living in a highly developed country with excellent infrastructure and plenty of possibility of developing the students talents and interests.

Keywords: USA university education; high quality educational services; higher education management; internationalization; activities of USA universities.

$\Pi$ остановка проблеми. Відомо, що якісні освітні послуги з валідним дипломом забезпечують заклади вищої освіти зі сучасною інфраструктурою, які здійснюють науково-дослідну роботу та сприяють міжнародній співпраціз метоюприваблення іноземних студентів, що означає отримання додаткового капіталу та можливість подальшого розвитку.

Питання вищої освіти та діяльності ЗВО США досліджували багато як українських науковців, таких як: С. Андріяш, С. Вітвицька, С. Калашнікова, Т. Кошманова, О. Липовецька, Т. Равчина,В. СаверськаЛихошва, так і зарубіжних, наприклад, П. Альтбах (Altbach, Р.), Л. Брайс (Brice L), І. Голм (Holm G.), А. Інкелес (Inkeles А.), Дж. Найт (Knight, J.), Л. Сіровий (Sirowy L.), Дж. Форест (Forest, J.) та інші. Вплив глобалізації та інтернаціоналізації на розвиток вищої освіти у США досліджували П. Альтбах, Дж. Найт та Дж. Форест; питання виховання мультикультурного викладача вивчали П. Альтбах, Л. Брайс, Г. Голм; громадянську педагогіку та сучасні методи викладання аналізували педагоги Т. Кошманова та Т. Равчина зарубіжний досвід управління освітою вивчали С. Вітвицька, С. Калашнікова та О. Липовецька, діяльність університетів “Ліги плюща” досліджували М. Краснянський, А. Інкелес та Л. Сіровий.

Та сьогодні не здійснено грунтовного аналізу та узагальнення характеристик якісної вищої освіти та передумов її розвитку на основі сучасного передового досвіду США $з$ метою можливого перейняття його для удосконалення системи вищої освіти України.

Метою статті $\epsilon$ розглянути й узагальнити характерні передумови забезпечення якісної університетської освіти США, її головні позитивні риси, дослідити американський досвід управління вищою освітою та проаналізувати статистичні дані світових рейтингів щодо престижності американських закладів вищої освіти.

Виклад основного матеріалу. Вищу освіту США характеризує “демократизм, повага до особистості, відсутність будь-якого тиску й примусу, панування самоконтролю, розвиток особистості, формування навичок подальшої самоосвіти, патріотизм" $[5,157$ - 160]. А якісна підготовка спеціалістів, здатних критично мислити, постійно розвиватися та працювати у полікультурному середовищі - іï завдання, а головною стратегією є їі інтернаціоналізація.
Діяльність сфери вищої освіти США регулюється відповідним законодавством Законом про вищу освіту (англ. The Higher Education Opportunity Act) 2008 р., складеним на основі закону від 1965 р. 3 поправками [15].

Відмінною рисою вищої освіти США від України є децентралізація управління, яке здійснюється на рівні штату. Департамент освіти США, здебільшого, реалізує загальне стратегічне планування розвитку вищої освіти, розподіл федеральних фінансових коштів на освіту, збір статистичних даних, керівництво різними інститутами та професійними організаціями. Законодавчі акти визначають функції місцевих органів управління освітою стосовно сертифікації, розвитку регіональних стандартів, фінансування та їхнього узгодження з федеральними органами влади. Кожен штат приймає свої закони щодо розвитку освіти. Освітня політика реалізується спеціальним державно-громадським органом Радою з освіти (англ. The State Board of Education), що складається 3 представників ділових кіл, бізнесменів, наукових товариств, професійних асоціацій, церковних громад, відомих громадських діячів тощо. Департамент освіти штату (англ. The Department of Education) $\epsilon$ виконавчим комітетом, який призначає Рада, i звітує перед нею [6].

Як зазначає О. Липовецька $3 \mathrm{BO} \epsilon$ автономними об'єднаннями під загальним наглядом суспільства (федерального уряду, урядів штатів як дистриб'юторів коштів відповідно до діючих законів) та фактичним керівництвом Ради 3 освіти кожного штату [6].

Результати дослідження Калашнікової (1999) засвідчують, що структура управління державною вищою освітою в США $\epsilon$ пірамідальною, тобто охоплює горизонтальний і вертикальний поділи. Горизонтальний поділ пов'язаний із участю в управлінні державних, громадських органів та органів самоврядування, вертикальний - передбачає наявність трьох адміністративних рівнів (федеральний (децентралізований), рівеньштату (децентралізований або централізований) та рівень закладу вищої освіти $[3,11]$. Авторка зазначає, що діяльність громадських освітніх асоціацій в управлінні вищою освітою є один із головних чинників розвитку американської вищої школи [3, 12 - 13].

Вітвицька подає інформацію, що загальне керівництво закладом вищої освіти здійснює й 
опікунська рада, до складу якої входить губернатор штату, якщо заклад державний; або голова промислової корпорації, релігійної общини чи приватна особа, якщо заклад приватний. Звертає на себе увагу велика кількість деканів, що відповідають за окремі ділянки роботи зі студентами, $є$ також органи самоврядування [2,319].

Згідно з Вітвицькою (2006), для США характерна різноманітність ЗВО, які не мають загальнонаціонального стандарту змісту навчання. Отож важливою є акредитація 3ВО (загальна акредитація або акредитація з окремих спеціальностей), що визначає його відповідність освітнім стандартам [2, 319].

Головною рисою вищої освіти США $є$ й те, що всі ЗВО пропонують платне навчання. Майже всі суспільства та співучасть в управлінні органів громадського управління; фінансова підтримка уряду; швидке реагування на нові виклики щодо підготовки фахівців. Негативними моментами є те, що навчання у всіх ЗВО є платним; відсутність централізованих механізмів для вирішення питань загальнонаціонального значення та існування певних проблем внутрішнього управління 3ВО через незбалансованість сфер повноважень та відповідальності тощо [3].

Високий рівень освіти, престижність та доступність 3ВО - це ті характеристики, які приваблюють здібну молодь $з$ усього світу. Фінансовий вклад іноземних студентів в економіку США, розвиток освіти та науки зростає 3 кожним роком (табл. 1).

Таблиця 1.

Фінансовий вклад іноземних студентів у вищу освіту США (IIE. Open Doors Report, 2016, 2017)

\begin{tabular}{|l|l|}
\hline Рік & Фінансовий вклад у доларах США \\
\hline 2014 p & 30,8 млрд. \\
\hline 2015 p. & 35 млрд. \\
\hline 2016 p. & 39,4 млрд. \\
\hline
\end{tabular}

приватні заклади є престижними. Серед державних закладів теж є університети, що надають студентам високий рівень освітніх послуг. Різниця між ними може бути лише в тому, що у більших університетах пропонують ширший вибір спеціалізації. Понад 70 \% усіх студентів навчаються у державних 3ВО. У приватному ЗВО може налічуватись від 100 студентів, а у державних - декілька десятків тисяч осіб (Степаненко, 2001). Плата за навчання у кожному закладі відрізняється і залежить від престижності ЗВО, його місцезнаходження, форми власності закладу, обраної спеціальності, факультету тощо. Уряд надає гранти, стипендії для фінансової підтримки здібної молоді. У країні є найбільша частка студентів із сімей робітників та фермерів, як і у Великій Британії [4].

Приходимо до висновку, що головними позитивними рисами у сфері управління вищою освітою США є їі децентралізована модель управління, що сприяє її гнучкому розвитку 3 урахуванням місцевих особливостей та глобальних тенденцій, стимулює ініціативу на місцевому рівні; дебюрократизована роль держави в розвитку вищої освіти; багатоцільовий і багатофункціональний характер вищої освіти (від забезпечення базових загальних знань до спеціалізації випускників 3ВО і аж до проведення фундаментальних досліджень); демократизм; автономність під загальним наглядом усього
Якість вищої освіти США підтверджують рейтинги міжнародних досліджень авторитетних видань і організацій, таких як: Топ-200 світовий рейтинг університетів видання “Times” (англ. Higher Education Top 200 World University Rankings), університетські рейтинги з якості освіти (англ. QS (Quality Standart) Top University Ranking), які оцінюють $3 \mathrm{BO}$ за результативністю навчання, дослідження (цитування), міжнародним світоглядом (міжнародна освітня діяльність), репутацією тощо. Згідно з цими даними, американські університети є уп'ятірці найкращих i складають найбільшу частку кращих університетів світу [12].

До десятки найкращих університетів США вже більше десяти років входять: Каліфорнійський технологічний інститут (штат Каліфорнія); Стенфордський університет (штат Каліфорнія); Массачусетський технологічний інститут (штат Массачусетс); Гарвардський університет (штат Массачусетс); Принстонський університет (штат Нью-Джерсі); Чиказький університет (штат Іллінойс); Університет Джона Гопкінса (штат Меріленд); Єльський університет (штат Коннектикут); Колумбійський університет (м. Нью-Йорк, штат Нью-Йорк); Каліфорнійський університет, Берклі (штат Каліфорнія) [12]. Безперечно, у рейтингу найкращих університетів світу завжди $є$ університети Ліги плюща (англ. Ivy League). 
Коледжі й університети США, навіть ті, які не потрапляють у такі престижні рейтинги, відомі високою якістю освіти, сучасними дослідницькими лабораторіями та навчальним обладнанням, гнучкістю освітніх програм.

Згідно із дослідженнями міжнародного інституту освіти - MIO (англ. International Institute of Education - IIE), інженерні науки, бізнес i менеджмент, математика, комп'ютерні науки користуються найбільшим попитом серед іноземних студентів (табл. 2) [11].
- розповсюджена практика консультацій психолога, студентського радника й академічного консультанта [8];

- індивідуальне навчання [1];

- забезпечення неперервної професійної освіти викладачів, виховання полікультурного викладача [7];

- організація дозвілля: різноманітність студентських об'єднань (братств, спортивних клубів та соціокультурних заходів), що сприяють соціокультурній адаптації [2];

- сучасна матеріально-технічна

Таблиця 2. база, відмінно оснащені бібліотеки, Найпопулярніші галузі знань серед іноземних студентів

\begin{tabular}{|c|c|}
\hline галузь знань & відсотки \\
\hline інженерні науки & $21,4 \%$ \\
\hline бізнес і менеджмент & $18,6 \%$ \\
\hline математика та інформатика & $15,5 \%$ \\
\hline соціальні науки & $7,7 \%$ \\
\hline
\end{tabular}
лабораторії тощо.

- практика обрання спеціальності (англ. major) після двох років навчання предметів загального циклу; можливість обрати подвійну спеціалізацію (англ. major \& minor);

- співпраця 3 бізнесом,

Американська вища освіта у цих сферах $\epsilon$ кращою, адже ЗВО мають чудове технічне оснащення аудиторій, укладені договори про співпрацю з бізнесом, з іноземними науковцями, що стимулює зацікавленість до навчання та науково-дослідної роботи.

ЗВО також виконують важливі соціальнокультурні функції (спортивні та культурні програми, волонтерство, програми неперервного навчання, консультаційні й експертні послуги, організація курсів різного змісту і тривалості усім, хто цікавиться новим і прагне до самовдосконалення).

МIO США виокремлює такі передумови забезпечення якості університетської освіти США: провідне становище США у світовій спільноті; центр інтелектуальних і науково-технічних досліджень і розвитку; велика кількість і різноманітність передових ЗВО; доступність вищої освіти; зразок децентралізованого управління в освітній сфері (керівництво здійснюють на рівні окремого штату); диплом міжнародного зразка [13].

Щодо організаційного контексту вищої освіти, то слід зазначити такі їі характерні позитивні та демократичні ознаки як:

- правильна державна політика у сфері освіти: децентралізація, демократизм, автономія, фінансування на основі ринкової економіки, фінансова підтримка не закладів, а студентів шляхом виділення грантів на навчання;

- система вищої освіти країни з багатоцільовим i багатофункціональним характером (від забезпечення базових загальних знань до спеціалізації випускників ЗВО та проведення фундаментальних досліджень) [1]; вченими з усього світу; $81-85]$

- відсутність корупції [4];

- доступність вищої освіти США: немає планового прийому і випуску спеціалістів у масштабах країни [2, 4-5].

- можливість отримання грантів, стипендій, навчання за програмами обміну.

Відмінний і змістовий контекст діяльності 3ВО, що відзначається такими позитивними характеристиками, як: отримання якісних знань та передового досвіду; широкий вибір сучасних спеціальностей; можливість записатися на орієнтаційні програми, програми доуніверситетської підготовку чи у центри англійської мови [9]; програми 3 полікультурним компонентом; приділення значної уваги здобуттю практичних навичок; досвід глобальної освіти у полікультурному середовищі, що передбачає успішну кар' єру.

Теоретико-методологічнийконтекст університетської освіти охоплює використання різноманітних педагогічних методів, насамперед активних методів навчання, студентоцентроване, коопероване навчання тощо для забезпечення якісних знань [7].

На міжнародному рівні освітня політика підтримує високі стандарти та спрямована на збільшення кількості іноземних студенів, охоплює:

- центральнукоординацію держави для вирішення стратегічних глобальних завдань вищої освіти, що здійснює Департамент освіти США (англ. The United States Department of Education) [15];
- діяльність центру кар'єрного розвитку [10, 
- інтенсивна рекрутингова діяльність ЗВО (рекламна кампанія, інформаційна діяльність освітніх організацій та консультаційних центрів у країні і за кордоном для пропагування навчання у США та підготовки до вступу [11];

- міжнародні угоди про співпрацю у сфері освіти з іншими країнами / державами [11];

Отже, важливими характеристиками якісної вищої освіти США, на нашу думку, $є$ : відповідність вищої освіти потребам глобальної економіки, великий вибір сучасних спеціальностей, якісна сучасна практична освіта 3 цінним дипломом у світі; програми з полікультурним компонентом; програми доуніверситетської підготовки та мовної підготовки; викладачі та вчені з практичним досвідом (вітчизняні та 3-за кордону), застосування ІТ-технологій; пропагування та здійснення наукових розвідок, проведення занять в аудиторіях 3 невеликою кількістю студентів; можливість навчання за індивідуальною програмою; практика обрання спеціальності після двох років навчання; активна діяльність консультаційних центрів із надання допомоги у навчанні, соціальній і культурній адаптації; сучасна матеріально-технічна база; можливість знайомства 3 потенційними роботодавцями; можливість вибороти гранти на навчання; відсутність корупції; досвід навчання у диверситивному середовищі; високий відсоток іноземних студентів; проживання у високо розвинугій країні з відмінною інфраструктурою та можливостями для розвитку талантів та інтересів кожного.

\section{ЛІТЕРАТУРА}

1. Андріяш С., Никитюк Т. Освіта у США. Інфосвіт (щомісячний додаток до газет “Управління освітою” та “Директор школи”), 2002. 6, C. 4-5.

2. Вітвицька С. (2006). Основи педагогіки вищої школи: підручник за модульно-рейтинговою системою навчання для студентів магістратури. Київ: Центр навчальної літератури.

3. Калашнікова С. А. Управління державним сектором вищої освіти в США. Автореф. дис. канд. наук $з$ державного управління: 25.00.05, Київ. 1999.

4. Краснянський, М. Ліга Плюща, або Вища освіта у США. Освітній портал.URL: www. Osvita.org.ua/articles/833.htlm//2011-10-25/2011.

5. Кошманова Т. Спільні та відмінні тенденції педагогічної освіти США у світовому контексті. Вісник Львівського університету. Серія педагогічна, 2003. 17, С.157-166.

6. Липовецька О. Зарубіжний досвід управління освітою регіону. Соціальна $i$ гуманітарна політика: вісник Національної Академії державного управління, 2013.С. 247251.

7. Мукан Н. В. Професійний розвиток науковопедагогічних працівників університетів. М. Євтух, Д. Герцюк, К. Шмідт (Ред.). Педагогічна освіта і наука в умовах класичного університету: традиції, проблеми, перспективи: у 3-х т. Т. 1. Підготовка педагогічних кадрів у вищій школі: виклики, проблеми, динаміка змін. Львів: ЛНУ імені Івана Франка, 2013. С. 380-386.

8. Освітній портал osvita.org.ua. Навчання у CШA. URL: www.osvita.ua/abroad/higher_school/ $\operatorname{articles} / 24433 / 2011$.

9. Саверська-Лихошва В. Освіта в США: Розвиток вищої освіти в США. Історія в школі, 9, 2003. C. 38-39.

10. Степаненко С. Система вищої освіти у США: фінансування і технологія. Вищяа школа, 6, 2001.71-87.

11. IIE. Open Doors Report Executive Summary \& Infographics. (2017). Available at: https:// www.iie.org/Why-IIE/Announcements/2017-11-13Open-Doors-2017-Executive-Summary)

12. QS (Quality Standard) World University Rankings 2015/16, 2016/2017, 2017/2018. Available at: https://www.topuniversities.com/universityrankings

13. Sirowy, L. \& Inkeles, A. (1984). Stanford University. University-level student exchanges: The US role in global perspective. Foreign student flows, their significance for American higher education, 7, pp.31-32.

14. The Times Higher Education World University Rankings. (2018). Available at: https:// www.timeshighereducation.com/world-universityrankings/2018/

15. United States Department of Education. (2017). Available at: http://www.ed.gov/)

\section{REFERENCES}

1. Andriyash, S. \& Nykytiuk, T. (2002). Osvita u SShA [Education in the USA]. Infosvit (schomisiachnyj dodatok do hazet "Upravlinnia osvitoyu” ta: Dyrector shkoly”) 6, pp. 4-5. [in Ukrainian].

2. Vitvytska, S. (2006). Osnovy pedagogiky vyschoyi shkoly: pidruchnyk za modulno-reitynhovoyu systemoyu navchannia dlia studentiv mahistratury [Fundamentals of higher education pedagogy: a textbook for modular-rating system of study for magisters]. Kyiv: Center for Educational Literature. [in Ukrainian].

3. Kalashnikova, S. A. (1999). Upravlinnia 
derzhavnym sectorom vyschoyi osvity u SShA. [US Department of State Public Sector Management]. Extended abstract of candidate's thesis. Kyiv. [in Ukrainian].

4. Krasnianskyj, M. (2011). Liha Pliuscha, abo vyscha osvita u SShA. [Ivy League or Higher Education in the USA]. Educational portal. Available at: www. Osvita.org.ua/articles/833.htlm// 2011-10-25/ [in Ukrainian].

5. Koshmanova, T. (2003). Spilni ta vidminni tendentsiyi pedahohichnoyi osvity SShA u svitovomu konteksti. [Common and distinctive trendenties in US pedagogical education in a global context]. Bulletin of Lviv University. Pedagogical series, 17, pp.157166. [in Ukrainian].

6. Lypovetska, O. (2013). Zarybizhnyi dosvid upravlinnia osvitoiu region. [Foreign experience in regional education management]. Social and Humanitarian Policy: Bulletin of the National Academy of Public Administration, pp.247-251. [in Ukrainian].

7. Mukan, N. V. (2013). Profesijnyj rozvytok naukovo-pedagogichnykh pratsivnykiv universytetiv. [Professional development of scientific and pedagogical university staff]. (Ed.). Yevtukh, M., Hertzyk, D., Schmidt, C.Vol. 1. Pedagogical training in high school: challenges, problems, dynamics of changes. Lviv: Ivan Franko LNU, pp.380-386. [in Ukrainian].

8. Osvitnij portal. osvita.org.ua. (2011). Navchannia u SShA. [Studying in the USA]. Available at: www.osvita.ua/abroad/higher_school/articles/24433/ [in Ukrainian].

9. Saverska-Lykhoshva, V. (2003). Osvita v SShA: Rozvytok vyschoi osvity v SShA. [Education in the USA: The development of higher education in the United States]. History in school, 9, pp. 38-39. [in Ukrainian].

10. Stepanenko S. (2001). Systema vyschoi osvity u SShA: finansuvannia i tekhnologia. [US Higher Education System: Financing and Technology]. High school, 6, pp. 71-87. [in Ukrainian].

11. IIE. Open Doors Report Executive Summary \& Infographics. (2017). Available at: https:// www.iie.org/Why-IIE/Announcements/2017-11-13Open-Doors-2017-Executive-Summary) [in English].

12. QS (Quality Standard) World University Rankings 2015/16, 2016/2017, 2017/2018. Available at: https://www.topuniversities.com/universityrankings [in English].

13. Sirowy, L. and Inkeles, A. (1984). Stanford University. University-level student exchanges: The US role in global perspective. Foreign student flows, their significance for American higher education, 7, pp. 31-32. [in English]

14. The Times Higher Education World University Rankings. (2018). Available at: https:// www.timeshighereducation.com/world-universityrankings/2018/ [in English].

15. United States Department of Education. (2017). Available at: http://www.ed.gov/) [in English].

Стаття надійшла до редакції 28.03.2019

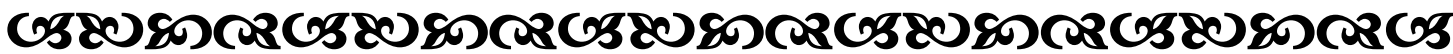

"Кожна людина повинна переважно братися за те, що для неї можливо і що для неї пристойно".

Apucmoтель

давньогрецький вчений-енщиклопедист

“Вивчай все не з марнославства, а задля практичної користі”.

Теоре Крістоб Аіхтенберг

німецький вчений науки".

“Всі люди в рівній мірі мають право на освіту і повинні користуватися плодами

ФрідріхЕнгельс

німецький ббілософ

“Вченість - це солоджий плід гіркого кореня”.

Iсокраm

давньогрецький ббілособб

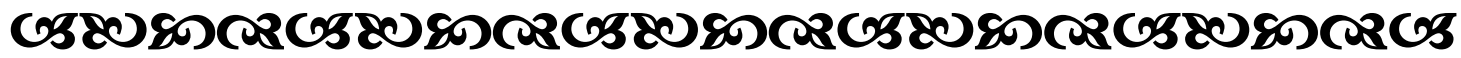

